\title{
Phoma Basal Rot of Romaine Lettuce in California Caused by Phoma exigua: Occurrence, Characterization, and Control
}

\author{
Steven T. Koike, University of California Cooperative Extension, Salinas 93901; Krishna V. Subbarao, Department \\ of Plant Pathology, University of California, Davis 95616; Gerard J. M. Verkley, Centraalbureau voor Schimmel- \\ cultures, P.O. Box 85167, 3508 AD Utrecht, The Netherlands; Diana Fogle, California Department of Food and Ag- \\ riculture, Sacramento 95832; Timothy M. O’Neill, ADAS UK Ltd., Cambs CB6 2BA, United Kingdom
}

\begin{abstract}
Koike, S. T., Subbarao, K. V., Verkley, G. J. M., Fogle, D., and O’Neill, T. M. 2006. Phoma basal rot of romaine lettuce in California caused by Phoma exigua: Occurrence, characterization, and control. Plant Dis. 90:1268-1275.

Beginning in 2000 and continuing into 2004, a previously undescribed disease caused significant damage to romaine lettuce (Lactuca sativa) in the coastal Salinas Valley of California. Symptoms were brownish black, sunken cavities on the crown and upper taproot. Cavities were firm, lacked signs of fungal growth, and resulted in cracking and weakening of the crown. Affected plants were stunted, uneven in growth, and unmarketable. Crisphead lettuce also developed these symptoms, although disease incidence was always lower than that for romaine. A fungus was consistently isolated from cavities. Using morphological features and molecular methods, the fungus was identified as Phoma exigua. Pathogenicity of isolates from romaine and crisphead lettuce was demonstrated on both of these lettuce types. Replicated field studies showed that azoxystrobin, boscalid, and cyprodinil + fludioxonil fungicides effectively controlled the disease. This is the first report of a crown disease caused by P. exigua in the United States. A similar disease, Phoma basal rot on greenhouse grown lettuce in the United Kingdom, had been previously observed, but no report has been published.
\end{abstract}

Additional keywords: Botrytis, Rhizoctonia, Sclerotinia

Lettuce (Lactuca sativa) is an important salad vegetable grown in California. In 2003, there were 93,890 ha of lettuce grown, with a farmgate value of $\$ 1.73$ billion, making California the leading producer of lettuce in the United States (19). The Salinas Valley (Monterey County) is located on the central coast and is the primary lettuce producing area for California, accounting for $59 \%$ of the state's production in 2003. In the last 3 to 4 years, consumer preference for romaine lettuce has increased greatly, and total romaine production has grown correspondingly. In 2004 , for the first time the value of the romaine crop exceeded that of crisphead lettuce and comprised $45 \%$ of the total Monterey County lettuce crop value (2).

In 2000, an unidentified disease of romaine was found in Santa Cruz County, adjacent to Monterey County (10). Since that first detection, the disease has recurred on romaine in the spring (March through May) each year and appeared in four central coast counties (Monterey, Santa Cruz,

Corresponding author: S. T. Koike

E-mail: stkoike@ucdavis.edu

Accepted for publication 30 May 2006.

DOI: 10.1094/PD-90-1268

() 2006 The American Phytopathological Society
San Benito, and Santa Barbara). The disease can severely affect romaine, with disease incidence ranging from 1 to $65 \%$. In addition to romaine lettuce, isolated cases of affected crisphead lettuce have been recorded since 2001, although disease incidence was always lower than that in romaine lettuce fields and ranged from 1 to $13 \%$. By 2005 , the disease was recorded in numerous fields planted to romaine in all four counties. The disease has been confirmed on romaine that is grown either conventionally or organically. To date, winter planted romaine (in the Huron region in California and Yuma, AZ) and early-season romaine in south coast California (Ventura County) have not been affected by this problem.

Initial foliar symptoms on romaine consist of yellowing and wilting of lower leaves (Fig. 1). Affected plants grow poorly and are stunted. As the disease progresses, the entire plant often wilts and collapses. These yellowing, wilting, and collapsing symptoms can resemble those caused by Botrytis cinerea and Sclerotinia species on lettuce. However, careful examination of the crowns of affected romaine reveals distinct symptoms. Diseased plants had characteristic black to dark brown, sunken cavities at the soil line on the crown and upper taproot. The cavities are firm, dry, and lack signs of fungal growth or fruiting bodies. On mature plants, the cavities measure up to 4 to $6 \mathrm{~cm}$ wide; however, these diseased areas typically remain on one side of the plant and do not girdle the lettuce crown. Cross sections of symptomatic crowns reveal cavities extending deep into the crowns, resulting in extensive weakening of the plant crown; these plants can be easily broken off at ground level. Longitudinal cuts made through the entire root and crown reveal that the dark brown cavity is restricted to the crown, but discolored black, brown, and red streaks extend from the crown into the taproot tissue or up into attached petioles (Fig. 2). At maturity, surviving diseased plants are asymmetrical because the side of the plant with the cavity is stunted while the unaffected side has normal growth. Symptoms on crisphead lettuce are similar, although it appears less susceptible to the problem. With the exception of one case, this disease was not observed on field plantings of greenleaf, redleaf, and butterhead lettuce types.

The purpose of this study was to identify the cause of the disease, characterize the pathogen, and develop management options for the grower. Preliminary reports have been published $(10,11)$.

\section{MATERIALS AND METHODS}

Isolation of the causal agent. Symptomatic crowns of romaine lettuce from commercial fields were surface-sterilized by soaking pieces in a $10 \%$ bleach $(0.525 \%$ sodium hypochlorite) solution for 5 min and then rinsing several times with sterile distilled water. Small (approximately $3 \times 3 \mathrm{~mm}$ ) sections of tissue were aseptically excised from the margins of the cavities and placed into petri plates containing either potato dextrose agar (PDA; Difco) that was acidified (2 $\mathrm{ml}$ of $25 \%$ lactic acid/liter) or PARP semiselective medium for Pythium/Phytophthora (9). PDA plates were incubated in light from a combination of cool-white and Vita-Lite fluorescent tubes on a 12-h light/dark cycle at $24^{\circ} \mathrm{C}$ and examined after 3 to 10 days for fungal growth. PARP plates were incubated in the dark and examined after 3 to 7 days. To test for possible bacterial pathogens, small pieces of the surface-sterilized crown tissue were aseptically excised from cavity margins and macerated in $40 \mu \mathrm{l}$ of sterile distilled water. The resulting suspensions were streaked onto sucrose pep- 
tone agar plates and incubated at $24^{\circ} \mathrm{C}$. After 2 to 5 days, these plates were examined for bacterial growth. Small pieces of nonsterilized crown tissue were also excised and mounted in water on glass slides to examine for bacterial streaming with a compound microscope.

From 2000 to 2004, sets of 10 symptomatic romaine plants were collected each year from five to eight fields located in the four affected counties. All plants were analyzed for the presence of possible pathogens as described. Hyphal tip cultures of isolated fungi were subsequently stored on PDA slants held at $5^{\circ} \mathrm{C}$. Isolates used in this study are stored with the Centraalbureau voor Schimmelcultures (CBS) and are listed in Table 1.

Examination for vascular colonization. Discoloration was exhibited in internal vascular and pith tissues in taproots and stem petioles. Therefore, we tested symptomatic plants to determine if a fungal pathogen was present in vascular or pith tissues distant from actual cavities. Intact crown-taproot romaine lettuce samples were surface-sterilized by soaking them in $10 \%$ bleach $(0.525 \%$ sodium hypochlorite) solutions for $5 \mathrm{~min}$ and then rinsing several times with sterile distilled water. For each sample, the crown-taproot was cut longitudinally and a small (approximately $3 \times 3$ $\mathrm{mm})$ section of tissue was aseptically excised from the lower and upper margins of the cavity. Subsequently, small tissue sections were excised from symptomatic vascular and pith root tissue below the cavity and vascular petiole tissue above the cavity. Such sections were taken at approximately $1-\mathrm{cm}$ distances. All excised pieces were arranged in sequential order and placed into petri plates containing acidified PDA. Plates were incubated as described above.
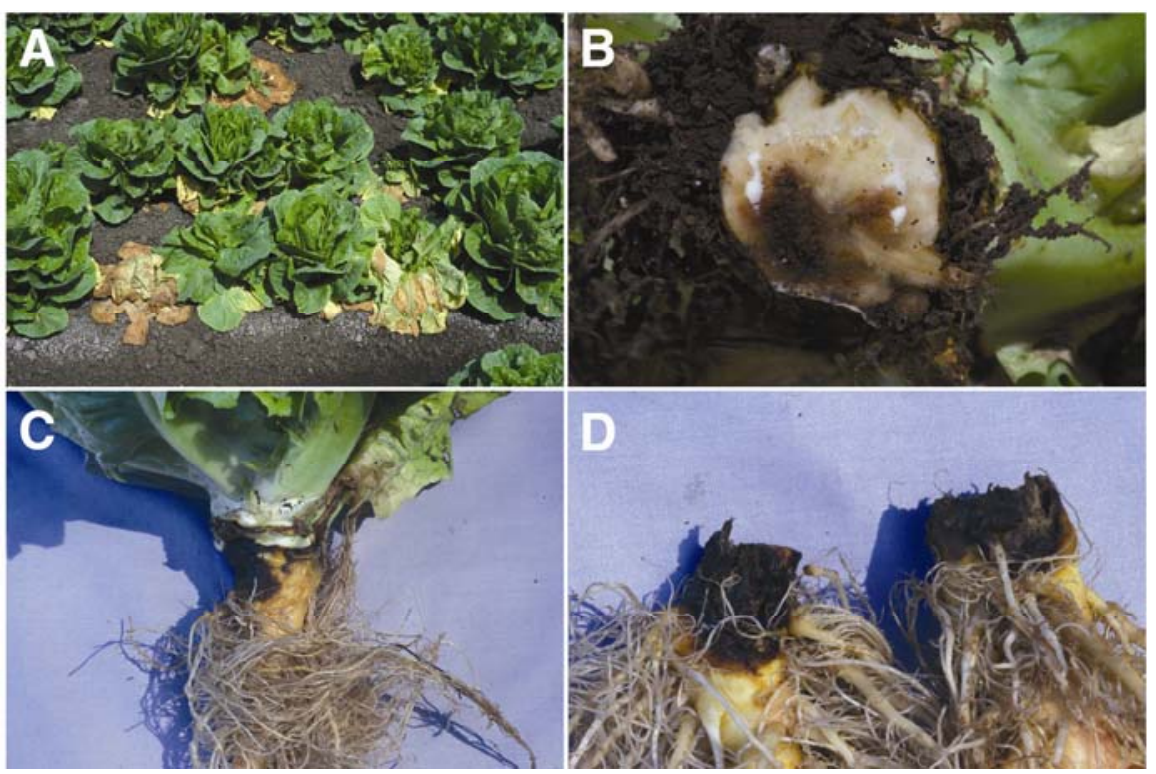

Fig. 1. Symptoms of Phoma basal rot of lettuce. A, Diseased plants wilt, turn brown, and collapse. B, Cross section at crown level shows penetration of the infection. C, Dark brown to black, irregularly shaped cavities form on the outside of crowns. D, Diseased crowns are structurally weak, and plants often break off at the crown.
Characterization of fungal isolates. For morphological identification, subcultures of selected isolates were incubated on oatmeal (OA), 3\% malt extract (MEA), and cherry decoction (CHA) agars in the dark for 7 days, and subsequently under $n$ UV (12-h cycles), at $18^{\circ} \mathrm{C}$. Colony pigmentation was described according to Rayner (17). Colony diameters were measured from all three media after 7 and 14 days, and conidial morphology and measurements were taken after 14 days from OA cultures. The presence of antibiotic $\mathrm{E}$ was tested by placing a drop of concentrated $\mathrm{NaOH}$ on the edge of colonies grown on MEA and observing for color changes (6). Identifications were made according to previously published reports (20).

Molecular characterization was done by sequencing the 5.8S ribosomal RNA gene and flanking spacer regions (ITS1, ITS2), and comparing results with reference strains from the CBS culture collection (1). For DNA isolation, strains were inoculated in $2 \mathrm{ml}$ of liquid medium ( $2 \%$ malt extract) and incubated for 2 to 3 weeks at room temperature. Liquid cultures were transferred to 2-ml tubes, centrifuged, and washed twice with sterile water. DNA was extracted using the FastDNAkit (Omnilabo 6050073, BIO 101, Q-Biogene, Irvine, CA). For ITS sequence analysis, a part of the ribosomal RNA gene cluster was amplified by PCR using primer pairs V9G (8) and LR5 (21). PCR was performed in 50$\mu \mathrm{l}$ reaction volumes, each reaction containing 10 to $100 \mathrm{ng}$ of DNA, $25 \mathrm{pM}$ of each primer, $40 \mu \mathrm{M}$ dNTP, 1.0 unit Supertaq DNA polymerase, and $5 \mu \mathrm{l}$ of $10 \times$ PCR buffer (SphaeroQ, Leiden, The Netherlands). The amplification was performed in an Applied Biosystems (Foster City, CA) thermocycler with the following program: $1 \min 95^{\circ} \mathrm{C}, 30 \times\left(1 \min 95^{\circ} \mathrm{C}, 1 \min 55^{\circ} \mathrm{C}\right.$ $2 \min 72^{\circ} \mathrm{C}$ ), followed by a final extension of $5 \mathrm{~min}$ at $72^{\circ} \mathrm{C}$. After cleaning PCR products with GFX columns (Amersham Pharmacia, Piscataway, NJ), the concentration of template was estimated on a $2 \%$ agarose gel. PCR products were sequenced with primers ITS1 and ITS4 (22) using BigDye terminator chemistry (Applied Biosystems). The sequencing products were cleaned with G50 Superfine Sephadex columns (Amersham Pharmacia), and separated and analyzed on an ABI Prism 3700 DNA Analyzer (Applied Biosystems). Forward and reverse sequences were matched using SeqMan (DNAstar Inc., Madison, WI).

Pathogenicity of isolates to lettuce and inoculation techniques. To prove pathogenicity, inoculum of eight isolates was prepared by growing each isolate on PDA for 2 weeks, then cutting out plugs of colonized agar (6 $\mathrm{mm}$ diameter). One colonized plug per plant was placed at the crown base of a 6-week-old, potted romaine lettuce seedling (cv. Parris Island), and was then covered by the rooting medium. Ten seedlings were inoculated for each isolate. Control plants were inoculated with sterile agar plugs. Plants were incubated in a greenhouse that was maintained at 21 to $25^{\circ} \mathrm{C}$. All plants were examined after 1 month, and symptomatic crown tissue was analyzed for the presence of fungi as described above. The experiment was conducted twice.

Different inoculation methods were evaluated in another set of experiments. Lettuce plants were direct-seeded into transplant trays and grown until they were 28 days old. Inoculum of two isolates, one

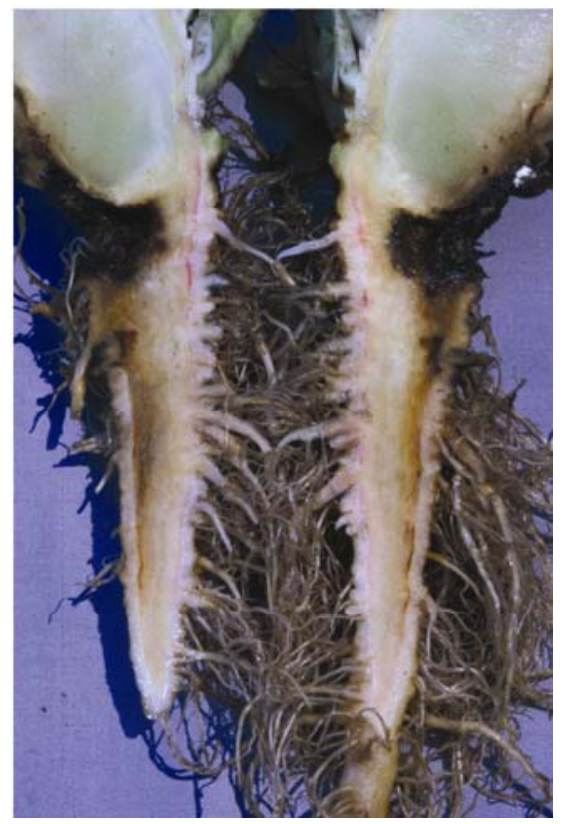

Fig. 2. Dissected crown and root of lettuce with Phoma basal rot, showing extent of crown cavity and discoloration in the taproot. 
obtained from romaine (Hal-12) and one pared by growing them on V8 juice agar. Three inoculation methods were tested with both isolates on romaine (cv. Parris Island) and crisphead (cv. Salinas) lettuce varieties. For method 1, roots of test plants were either left intact or clipped, and then roots and crowns were soaked in spore suspensions $\left(1 \times 10^{6}\right.$ conidia $\left./ \mathrm{ml}\right)$ for 15 min before potting. For method 2, colonized agar blocks were placed at the crown base of plants and then covered with potting mix. For method $3,1 \mathrm{ml}$ of a spore suspension $\left(1 \times 10^{6}\right.$ conidia/ml $)$ was poured onto the base of potted plants. Control plants received either water (methods 1 and 3 ) or sterile agar blocks (method 2). Plants were incubated in a greenhouse that was maintained at 21 to $25^{\circ} \mathrm{C}$. All plants were examined after 50 to 55 days, and symptomatic crown tissue was analyzed for the presence of the pathogen as described above. Treatments were replicated five times each, and the experiment was conducted twice.

Fungicide evaluations. Field trials in Monterey and Santa Cruz counties were set up in 2002 and 2003 to investigate the efficacy of fungicides for controlling the disease. Selected commercial fields had a history of Phoma basal rot on romaine lettuce, and for these trials romaine was direct-seeded and grown according to commercial standards (two rows of lettuce per bed; plants thinned to $30-\mathrm{cm}$ spacing). All trials were arranged in randomized tions. Plot sizes were usually two beds from crisphead lettuce (Rich-1), was precomplete block designs with four replica-

wide (1-m-wide beds) and $9.2 \mathrm{~m}$ long. Sprays were applied to the crowns of lettuce plants using a $\mathrm{CO}_{2}$ backpack sprayer set at $240 \mathrm{kPa}$, a two-nozzle hand-held boom (0.48-m spacing), and Teejet 6505 flat fan nozzles. To ensure thorough coverage, materials were applied in the equivalent of 1,120 liters of water per hectare.

In the first two trials (2002 and 2003), the first spray was applied 1 day after the lettuce was thinned, followed by two additional sprays at 1-week intervals each. Treatments included the following fungicides and rates per ha: pyraclostrobin + boscalid (Pristine), $1.62 \mathrm{~kg}$; boscalid (Endura), 399 and $560 \mathrm{~g}$; cyprodinil + fludioxonil (Switch 62.5 WG), $980 \mathrm{~g}$; azoxystrobin (Quadris Flowable), 0.93 and 1.12 liter; dicloran (Botran 5F), 7.0 liters; trifloxystrobin (Flint), $210 \mathrm{~g}$; pyraclostrobin (Cabrio EG), $1.12 \mathrm{~kg}$; iprodione (Rovral 4F), 2.34 liters; maneb (Maneb 75 DF), $2.24 \mathrm{~kg}$; benzothiadiazole (Actigard 50 WG), $93 \mathrm{~g}$; and untreated control. Treatments were evaluated at harvest by cutting 100 plants per plot and evaluating them for presence/absence of Phoma basal rot. Analysis of variance was completed on the data, and treatment means were compared using Fisher's protected LSD. All analyses were conducted using the Statgraphics statistical program (Rockville, MD).

The most effective fungicides in the first set of experiments were tested in the second set of field trials (three experiments in 2003) so that fungicide rates and timing could be evaluated. Boscalid (Endura at 399 and $560 \mathrm{~g} / \mathrm{ha}$ ) and azoxystrobin (Quadris Flowable at 0.76 and 1.12 li-

Table 1. Phoma exigua isolates from lettuce used in this study

\begin{tabular}{lll}
\hline Isolate & CBS number & Source \\
\hline Lewis 1 & CBS 118798 & California \\
Lewis 3 & CBS 118799 & California \\
Mason 27 & CBS 118800 & California \\
Mason 28 & CBS 118801 & California \\
Hal 11 & CBS 118802 & California \\
E45 & CBS 118803 & California \\
Hal 10 & CBS 118804 & California \\
C50 & CBS 118805 & California \\
SN & CBS 118806 & California \\
Hal 12 & CBS 118807 & California \\
CC 543 & $\ldots$ & United Kingdom \\
\hline
\end{tabular}

${ }^{\mathrm{z}} \mathrm{CBS}=$ Centraalbureau voor Schimmelcultures.

Table 2. Diagnostic guide for the crown rot diseases affecting lettuce in California

\begin{tabular}{llc}
\hline Pathogen (disease name) & Crown symptoms & Pathogen signs on crowns \\
\hline $\begin{array}{l}\text { Sclerotinia minor and } \\
\begin{array}{l}\text { S. sclerotiorum } \\
\text { (lettuce drop) }\end{array}\end{array}$ & $\begin{array}{c}\text { Very soft, mushy, watery rot; decay } \\
\text { is tan to brown; affects entire crown }\end{array}$ & $\begin{array}{c}\text { Extensive white mycelium; } \\
\text { black sclerotia }\end{array}$ \\
$\begin{array}{c}\text { Botrytis cinerea } \\
\text { (gray mold) }\end{array}$ & $\begin{array}{c}\text { Very soft, mushy, watery rot; decay } \\
\text { is brown to orange; affects entire }\end{array}$ & $\begin{array}{c}\text { Extensive gray sporulation; } \\
\text { (sclerotia are uncommon) }\end{array}$ \\
$\begin{array}{c}\text { crown } \\
\text { Rhizoctonia solani }\end{array}$ & $\begin{array}{c}\text { Usually firm, dry, sunken lesions; } \\
\text { lbottom rot) }\end{array}$ & $\begin{array}{c}\text { Brown mycelial strands in } \\
\text { lesion (not always readily } \\
\text { visible) }\end{array}$ \\
$\begin{array}{c}\text { Phoma exigua } \\
\text { (Phoma basal rot) }\end{array}$ & Firm, sunken, irregular cavity; cavity & None \\
& is dark brown to black; cavity & \\
\hline
\end{tabular}

ter/ha) were applied at different rates with either one or two applications. The first spray was applied 1 day after thinning. If a second spray was scheduled, it was applied 1 week later. Application methods were the same as those used in the first field trials. Treatments were evaluated at harvest by cutting 100 plants per plot and evaluating them for presence/absence of Phoma basal rot disease. Analysis of variance was completed on the data and treatment means were compared using Fisher's protected LSD. All analyses were conducted using the Statgraphics statistical program (Rockville, MD).

\section{RESULTS}

Isolation of the causal agent. One type of fungus was isolated consistently from symptomatic crowns of romaine and crisphead lettuce samples in all years and from all locations. Isolated colonies on acidified PDA were gray-green, with white felty aerial mycelium, had irregularly lobed radial growth, and did not produce reproductive structures on this medium. No organisms were recovered on PARP plates. No bacteria were recovered from the suspensions prepared from symptomatic crown tissue and streaked onto sucrose peptone agar plates. No bacterial streaming was observed when tissue pieces were examined microscopically. No other known lettuce pathogens were recovered from plants exhibiting the crown cavity symptoms, nor were sclerotia or fungal signs observed on affected tissues. Pathogens such as Botrytis cinerea, Rhizoctonia solani, and Sclerotinia species (S. minor and $S$. sclerotiorum) were not isolated, even though some of the symptoms caused by these organisms resemble this new crown rot problem (Table 2).

Examination for vascular colonization. When intact crowns and roots were dissected longitudinally and excised pieces were cultured for fungi, only the tissues removed from the lower and upper margins of the crown cavities resulted in the recovery of gray-green isolates. No fungi were recovered from tissues that were removed from discolored vascular and pith tissue in the roots and vascular tissue in petioles. The results were the same for all samples tested.

Characterization of fungal isolates. All isolates recovered from symptomatic romaine and crisphead lettuce were morphologically similar and identified as Phoma exigua, based on the colony characters and sporulation as described by van der Aa et al. (20) and Boerema et al. (5). On lettuce in the United Kingdom, $P$. exigua caused a disease called Phoma basal rot (15). We therefore also refer to the disease observed in California as Phoma basal rot.

Colonies on OA had diameters of 66 to $78 \mathrm{~mm}$ in 7 days; all colonies reached the edges of petri plates after 14 days; these 
diameters are recorded as $>85 \mathrm{~mm}$ (Fig. 3, Table 3). Colonies had colorless, glabrous, regularly lobed margins. Colonies as viewed from above were olivaceous with a shade of honey (in a patchy and radiating pattern). Aerial mycelium was absent or very scanty, whitish, floccose, later with whitish tufts of aerial mycelium scattered all over the colony surface. Colony reverse sides were hazel or honey to isabelline, or vinaceous buff to fawn, but later had more olivaceous coloring, especially near the margins. Isolate Lewis 3 produced a red pigment. Sporulation occurred in superficial pycnidia within a few days, with spore slime whitish, flesh, or salmon colored. No chlamydospores were observed.

Colonies on MEA had diameters of 37 to $58 \mathrm{~mm}$ in 7 days and 45 to $75 \mathrm{~mm}$ in 14 days, with irregularly lobed, colorless to slightly salmon (isolate Lewis 3), almost glabrous margins (Fig. 3, Table 3). Viewed from above, colonies were greenish gray to somewhat olivaceous gray in the center and were surrounded by greenish olivaceous and olivaceous buff zones. Colony surfaces were mostly covered by initially concolorous to grayish white, later mostly gray, well-developed woolly-floccose aerial mycelium. Colony reverse sides were mostly olivaceous black or sepia, surrounded by an irregularly outlined, ochreous submarginal zone. Colonies sporulated abundantly after 10 days, and spore slime had similar coloration to that seen on OA cultures.

Colonies on CHA had diameters of 34 to $58 \mathrm{~mm}$ in 7 days and 54 to $73 \mathrm{~mm}$ in 14 days, with irregularly lobed, pale ochreous to salmon margins. Viewed from above, colonies were glaucous blue-green to dull green. After 14 days, colonies became darker olivaceous and surfaces were mostly covered by a diffuse but high mat of grayish, woolly-floccose aerial mycelium. Colony reverse sides were mostly sepia or dark brick, with well defined, ochreous to saffron or brick and cinnamon marginal zones.

Pycnidia developing after 5 to 7 days were characteristic of $P$. exigua var. exigua. Conidia on OA were subglobose, ellipsoid to oblong, or almost cylindrical, with rounded, rarely truncate ends, or pyriform, with one attenuated end, aseptate or 1(-2)septate, often constricted at the septa, with several small guttules near the ends (Fig. $3)$. Conidial measurements on OA were in the range of $(3.8-) 4.5$ to $7.5(-10.0) \times$ (1.7-) 2.0 to $3.0(-3.5)$ for 1-celled conidia and 7.2 to $10.2 \times 2.1$ to $4 \mu \mathrm{m}$ for 2 -celled conidia.

Adding drops of $\mathrm{NaOH}$ to the edges of actively growing isolates on MEA did not result in any color changes to the medium. The agar did not turn blue-green (initial reaction) or red-brown (later reaction), indicating that antibiotic $\mathrm{E}$ was not present. ITS sequences of all strains analyzed were $100 \%$ identical to the sequences of $P$. exigua var. exigua strain CBS 101156 (AF168182) and strains of other varieties of P. exigua (1).

Pathogenicity of isolates to lettuce and inoculation techniques. All eight isolates of $P$. exigua from romaine lettuce caused the formation of typical dark crown cavities on inoculated romaine plants. Affected plants grew poorly and were stunted. Symptoms were similar to those observed in commercial romaine fields. Disease incidence ranged from 30 to $50 \%$. Fungi similar to the original isolates were recovered from all symptomatic tissues and were confirmed to be $P$. exigua. Uninoculated controls remained symptomless, and results from the two experiments were similar.

All inoculation methods resulted in consistent reproduction of Phoma basal rot symptoms consisting of crown cavities and stunting, which were similar to those seen in the field (Table 4). Root dip and drench methods were most consistent and resulted in $100 \%$ disease; the agar block method resulted in slightly fewer diseased plants. None of these inoculation methods resulted in significant discoloration in vascular tissue above or below the crown cavities. The fungus was reisolated from crown tissue in all cases for all methods. Uninoculated controls remained symptomless, and results from the two experiments were similar.

The inoculation experiments also demonstrated that romaine and crisphead isolates of $P$. exigua were not specific to a particular lettuce type (Table 4). The romaine isolate was consistently pathogenic on romaine and crisphead cultivars. Likewise, the crisphead isolate was consistently pathogenic on crisphead and romaine cultivars. There was no apparent difference in virulence between the romaine and crisphead isolates.

Fungicide evaluations. There were statistically significant differences in disease incidence between fungicide treatments in all experiments. In the 2002 field trial, pyraclostrobin + boscalid $(0.7 \%)$, cyprodinil + fludioxonil $(6.3 \%)$, and azoxystrobin $(9.7 \%)$ resulted in excellent control of Phoma basal rot compared with untreated controls $(30.0 \%)$ (Table 5). Applications of pyraclostrobin alone (one of the two components of the Pristine prod- uct) and trifloxystrobin were significantly better than untreated controls, but were not as effective as the first three treatments. The three remaining treatments (maneb, dicloran, and benzothiadiazole) were not significantly better than the untreated control.

Because Pristine (pyraclostrobin + boscalid) is commercially available in its separate components, we added boscalid (Endura) to the 2003A field trial. Overall results were similar (Table 5). Pyraclostrobin + boscalid, boscalid alone at high and low rates, and cyprodinil + fludioxonil all had approximately $1 \%$ or lower disease incidence, while untreated control plots averaged $29 \%$. A second group of six other treatments (two rates of azoxystrobin, dicloran, trifloxystrobin, pyraclostrobin alone, and iprodione) performed well and had disease incidences (between 7 and $11 \%$ ) that were significantly better than untreated control. Two remaining treatments (maneb and benzothiadiazole) did not significantly control Phoma basal rot.

For fungicide trials 2003B, C, and D, we selected the top performing fungicides from trials in 2002 and 2003 that were either already registered for use on lettuce (azoxystrobin) or likely to be registered (boscalid). Results for trials 2003B (Table 6) and $2003 \mathrm{C}$ (data not shown) were similar. For trial 2003B, high rates of boscalid applied once or twice, low rate of boscalid applied twice, and high or low rates of azoxystrobin applied twice all resulted in Phoma basal rot incidences of less than $1 \%$. Azoxystrobin applied once at the high rate resulted in $3.4 \%$ disease. Untreated plots had $12.5 \%$ disease.

Disease control results in trial 2003D were notable because the first fungicide applications were applied 8 days late due to an unscheduled irrigation that delayed the first sprays. As a result, all fungicide treatments had Phoma basal rot disease incidences of greater than $10 \%$, with untreated control values averaging $21.9 \%$ (Table 6). In contrast with trials 2003B and C, two boscalid (14.1 and 19.1\%) and one azoxystrobin $(16.6 \%)$ treatments were not significantly different than the untreated control $(21.9 \%)$.

\section{DISCUSSION}

This is the first report of Phoma basal rot, caused by Phoma exigua, on lettuce in

Table 3. Maximum colony diameters of three Phoma exigua strains on three media after 7 and 14 days of incubation

\begin{tabular}{|c|c|c|c|c|c|c|}
\hline \multirow[b]{3}{*}{ Strain } & \multicolumn{6}{|c|}{ Maximum colony diameter $(\mathbf{m m})^{x}$} \\
\hline & \multicolumn{2}{|c|}{$\mathbf{O A}^{\mathbf{y}}$} & \multicolumn{2}{|c|}{ MEA $^{y}$} & \multicolumn{2}{|c|}{$\mathrm{CHA}^{\mathbf{y}}$} \\
\hline & 7 days & 14 days & 7 days & 14 days & 7 days & 14 days \\
\hline Lewis 3 & $76.0 \pm 2.0$ & $>85^{\mathrm{z}}$ & $47.7 \pm 1.2$ & $66.3 \pm 2.1$ & $53.5 \pm 5.0$ & $71.0 \pm 1.7$ \\
\hline Mason 27 & $67.3 \pm 1.2$ & $>85^{\mathrm{z}}$ & $37.7 \pm 0.6$ & $44.7 \pm 5.5$ & $36.6 \pm 2.1$ & $54.7 \pm 0.6$ \\
\hline Hal 12 & $69.0 \pm 1.0$ & $>85^{\mathrm{z}}$ & $56.3 \pm 1.5$ & $70.0 \pm 4.4$ & $46.3 \pm 1.5$ & $63.7 \pm 1.2$ \\
\hline
\end{tabular}

$x$ Values given are averages $\pm \mathrm{SD}$ with $\mathrm{N}=3$.

y $\mathrm{OA}=$ oatmeal agar; $\mathrm{MEA}=3 \%$ malt extract agar; $\mathrm{CHA}=$ cherry decoction agar.

${ }^{\mathrm{z}}$ Colonies reached the edge of petri plates. 
the United States. The observed ranges in colony pigmentations and growth rates for this set of isolates from lettuce fall within the expected variation of reference strains of $P$. exigua var. exigua from the CBS culture collection that have been used in previous studies of $P$. exigua varieties $(1,7,20)$. As documented in this study, Phoma basal rot has caused significant losses on romaine grown in California since its first occurrence in 2000. Disease distribution was initially limited to fields in Santa Cruz County. However, Phoma basal rot currently has been recorded in diverse parts of Santa Cruz, San Benito, Monterey, and Santa Barbara counties, all part of the central coast lettuce producing region of the state. In commercial fields, the disease has caused significant losses on romaine cultivars, has been less severe on crisphead cultivars, and has so far been found only one time on a greenleaf variety.
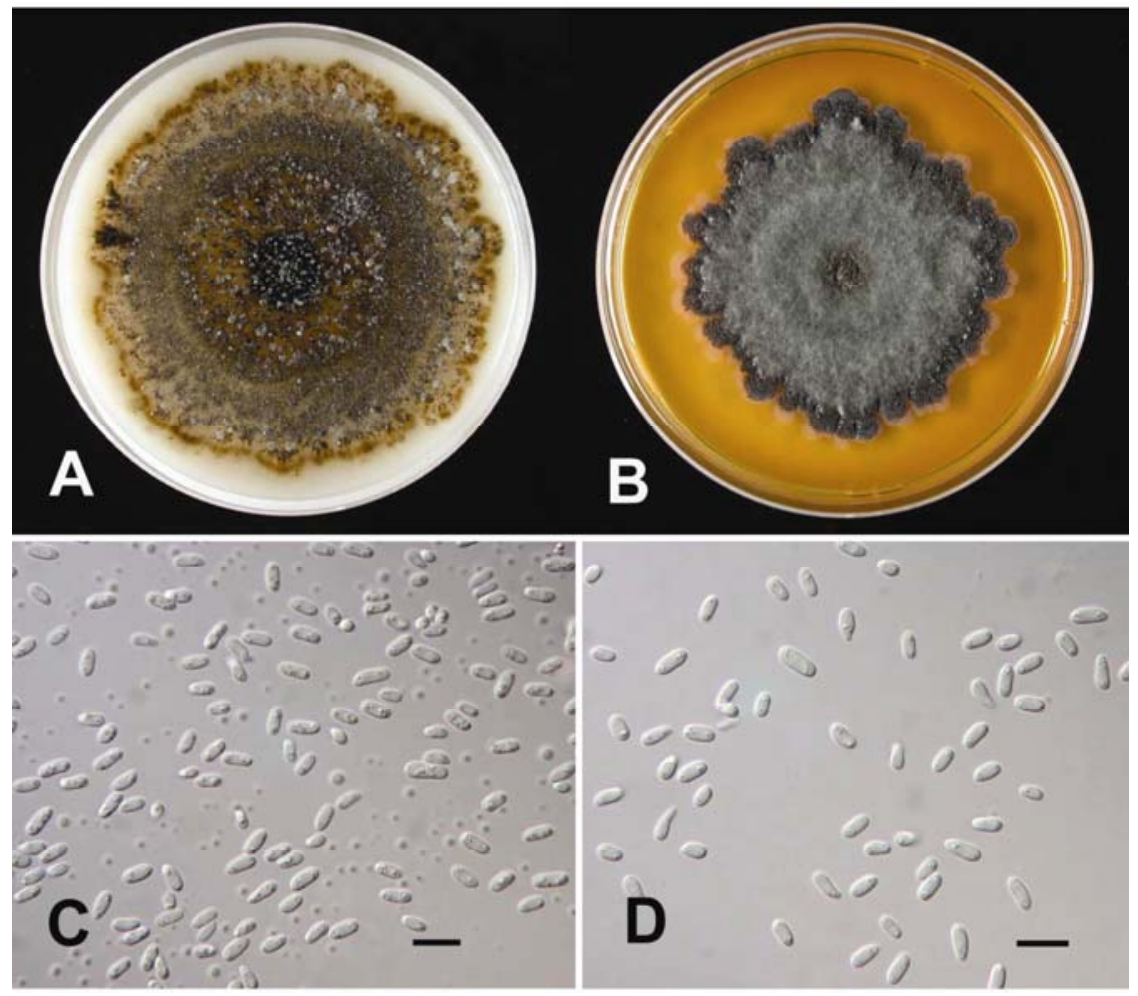

Fig. 3. Cultures and conidia of Phoma exigua isolates from lettuce: 14-day-old cultures of isolate Hal $12 \mathbf{A}$, on oatmeal agar and $\mathbf{B}$, on malt extract agar; conidia from 14-day-old oatmeal agar cultures of isolates $\mathbf{C}$, Hal 10 and D, Lewis 3. Bars $=10 \mu \mathrm{m}$.

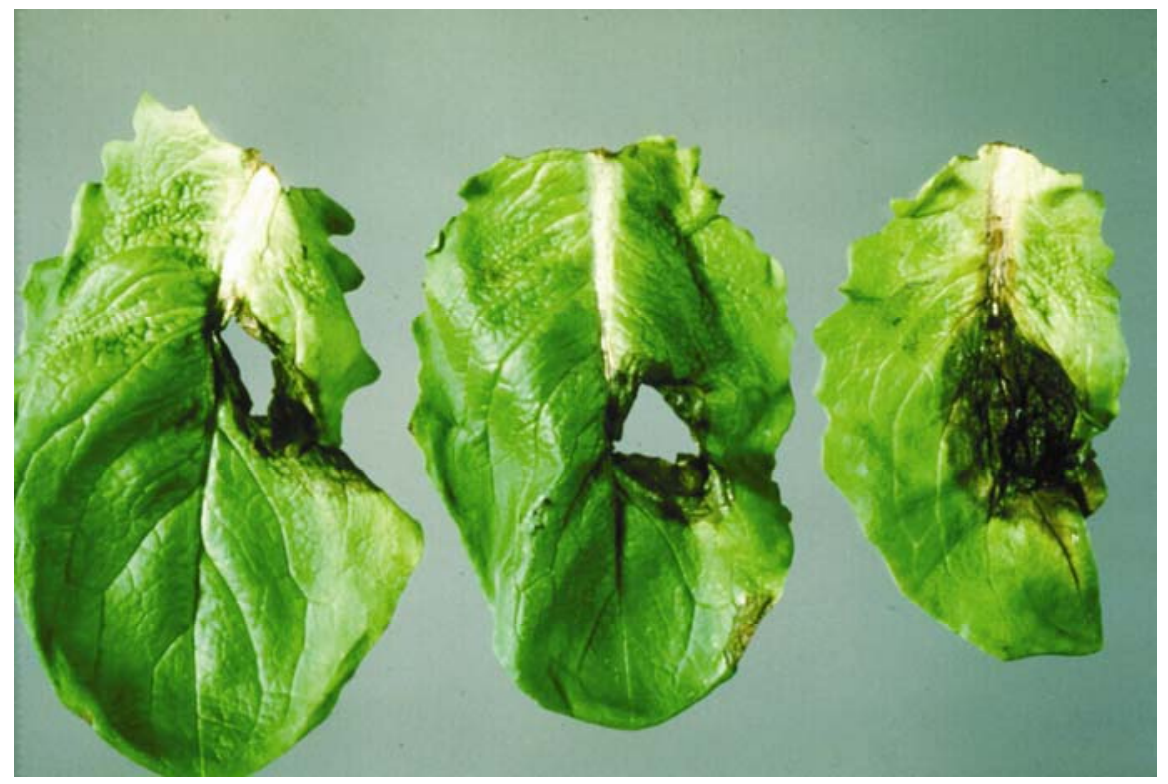

Fig. 4. Leaf spot symptom caused by Phoma exigua on greenhouse-grown lettuce in the United Kingdom.
It is interesting to note that virtually concurrent with the steep increase in the market popularity of romaine and planted acreage of this lettuce type, two diseases also appeared in California that affect primarily romaine lettuce. Phoma basal rot, documented in this report, and lettuce dieback, caused by Lettuce necrotic stunt virus (14), both were first detected and became serious problems in the early 2000s.

Pathogenicity experiments demonstrated that $P$. exigua isolates from romaine or crisphead can infect either type of lettuce. Of all inoculation methods compared in this study, direct placement of colonized agar plugs resulted in less consistent disease than soaking plants in or drenching plants with conidial inoculum. None of the inoculation methods resulted in diseased roots or vascular symptoms, and isolations from discolored vascular tissue of field samples never resulted in the isolation of $P$. exigua. These results are consistent with the general literature, which shows that $P$. exigua is not a pathogen of roots or vascular tissue $(13,18)$. The discoloration of internal lettuce tissues distant to the cavity appears to be a wound response to the cavity infection.

Cavities of this disease were not colonized by pathogenic bacteria or other known crown pathogens of lettuce, and Phoma basal rot symptoms on crowns differ significantly from those of other lettuce crown diseases in California. In contrast to the firm, dry, blackish cavity of Phoma basal rot, lettuce drop caused by Sclerotinia minor and $S$. sclerotiorum causes a soft, watery, mushy rot that is tan to brown. The characteristic white fluffy mycelium and black sclerotia of Sclerotinia species form at the crown. Gray mold, caused by Botrytis cinerea, also causes a soft, watery rot of the crown, although infected crown tissues are often more orange to brown. The powdery gray sporulation of $B$. cinerea is often present on diseased tissues, although large black sclerotia are seen only occasionally on lettuce. Bottom rot, caused by Rhizoctonia solani, is not common on lettuce in the coastal California area. When present, this disease causes discrete, firm, sunken brown lesions primarily on lettuce petiole tissue that is in contact with soil. If disease becomes more severe, lesions can extend into lettuce crown tissue. Because overall plant collapse symptoms are identical for all these crown rot problems, farmers, pest control advisors, and other field personnel will need to carefully examine lettuce crown tissue so that the various crown rot diseases can be distinguished from each other and diagnosed.

The genus Phoma (Section Phyllostictoides) comprises soilborne fungi that produce ostiolate, thin-walled pycnidia that are not borne in stromata, and hyaline, mostly single-celled conidia. As such, 
Phoma is the largest genus in the Sphaeropsidales, containing a very large number of species. Over 2000 species had been described by 1980 alone (18), although the taxonomic scheme for Phoma continues to be widely debated. P. exigua has a long and complicated taxonomic history, in part because this species is found widely throughout the world and is encountered as both a pathogen of many hosts and a common saprophyte (13). $P$. exigua is reported to cause a number of diseases, including damping-off, leaf spots, stem lesions, bark necrosis, and postharvest rots of fleshy roots and tubers.

Morphological and physiological differences exist among isolates from different hosts. In an attempt to organize the unwieldy number of reported $P$. exigua pathogens and to recognize differences among isolates, the concept of variety has been employed (4). Currently, nine varieties of $P$. exigua are proposed $(7,20)$. Most of these varieties are based on phenotypic characters and are also strongly supported by molecular genetic analysis (1). The first, P. exigua var. exigua, is plurivorous and has been reported to infect over 200 plant hosts, including some of those hosts infected by other, more host-specific $P$. exigua varieties. The other $P$. exigua varieties and their primary hosts are the following: var. linicola on flax (Linum usitatissimum), var. heteromorpha on oleander (Nerium oleander), var. populi on poplar (Populus nigra), var. diversispora on cowpea (Vigna unguiculata) and bean (Phaseolus vulgaris), var. noackiana on bean (Phaseolus vulgaris), var. lilacis on lilac (Syringa vulgaris), var. viburni on viburnum (Viburnum species) and honeysuckle (Lonicera species), and var. forsythiae on forsythia (Forsythia species).

For all lettuce isolates, the $\mathrm{NaOH}$ oxidation reaction for antibiotic $\mathrm{E}$ was negative even after prolonged incubation of MEA cultures under n-UV or daylight. Antibiotic $\mathrm{E}$ is a colorless metabolite that is characteristic of $P$. exigua varieties exigua and linicola, and is best expressed on malt agar cultures incubated in light (6). A positive reaction has also been observed in some isolates of $P$. exigua var. heteromorpha $(5,20)$, indicating that this reaction can vary within a variety of $P$. exigua. All other varieties are thus far consistently negative for antibiotic $\mathrm{E}$ production. Under alkaline conditions, this antibiotic $\mathrm{E}$ forms pigments $\alpha$ and $\beta$. Logan and O'Neill (12) found that antibiotic $\mathrm{E}$ is antagonistic to a number of bacteria and fungi.

We were unable to obtain reproducible results by amplified fragment length polymorphism (AFLP) and random amplified polymorphic DNA (RAPD) analyses. On the basis of the available data, including the ITS sequence, we conclude that the lettuce pathogen belongs to the species (complex) P. exigua, and that it could be $P$. exigua var. exigua. However, because of the absence of antibiotic E in MEA cultures, which is normally produced by this variety, further work is needed to settle its exact identity.

Studies completed over 2 years demonstrated that fungicides effectively minimize the incidence of Phoma basal rot in California. Effective control of this disease by fungicides in our trials provides additional

Table 4. Pathogenicity of Phoma exigua isolates to romaine and crisphead lettuce using various inoculation methods

\begin{tabular}{llrr}
\hline Lettuce cultivar & Inoculation method & $\begin{array}{c}\text { Phoma basal } \\
\text { rot }(\boldsymbol{\%})^{\mathbf{y}}\end{array}$ & $\begin{array}{c}\text { Reisolation of } \\
\boldsymbol{P} \text { exigua }(\boldsymbol{\%})^{\mathbf{z}}\end{array}$ \\
\hline P. exigua (isolate Hal-12) from romaine lettuce & & \\
Parris Island (romaine) & Roots unclipped, plants dipped & 100 & 100 \\
& Roots clipped, plants dipped & 100 & 100 \\
& Agar block placed at crown & 70 & 100 \\
& Crown drench & 100 & 100 \\
& Untreated & 0 & 0 \\
Salinas (crisphead) & Roots unclipped, plants dipped & 100 & 100 \\
& Roots clipped, plants dipped & 100 & 100 \\
& Agar block placed at crown & 50 & 100 \\
& Crown drench & 100 & 100 \\
& Untreated & 0 & 0 \\
Parris Island (romaine) & Roots unclipped, plants dipped & 100 & 100 \\
& Roots clipped, plants dipped & 100 & 100 \\
& Agar block placed at crown & 80 & 100 \\
& Crown drench & 100 & 100 \\
& Untreated & 0 & 0 \\
& Roots unclipped, plants dipped & 100 & 100 \\
& Roots clipped, plants dipped & 100 & 100 \\
& Agar block placed at crown & 70 & 100 \\
& Crown drench & 100 & 100 \\
& Untreated & 0 & 0 \\
\hline
\end{tabular}

$\bar{x}$ Inoculation methods: roots of test plants were either left intact or clipped, and then roots and crowns were soaked in spore suspensions $\left(1 \times 10^{6}\right.$ conidia/ml $)$ for $15 \mathrm{~min}$ before potting; colonized agar blocks were placed at the crown base of plants and then covered with potting mix; $1 \mathrm{ml}$ of a spore suspension $\left(1 \times 10^{6}\right.$ conidia/ml $)$ was poured onto the base of potted plants. Control plants received either water or sterile agar blocks.

y Percent plants that showed crown symptoms after 50 to 55 days.

${ }^{\mathrm{z}}$ For plants showing crown cavity symptoms, percent isolations that resulted in $P$. exigua colonies.

Table 5. Efficacy of fungicides for control of Phoma basal rot of romaine in 2002 and 2003

\begin{tabular}{|c|c|c|}
\hline Treatment $^{y}$ & Rate/ha & $\begin{array}{c}\text { Phoma basal } \\
\text { rot }(\%)^{\mathrm{z}}\end{array}$ \\
\hline \multicolumn{3}{|l|}{ Field trial 2002} \\
\hline Pyraclostrobin + boscalid (Pristine) & $1.62 \mathrm{~kg}$ & 0.7 \\
\hline Cyprodinil + fludioxonil (Switch 62.5 WG) & $980 \mathrm{~g}$ & 6.3 \\
\hline Azoxystrobin (Quadris Flowable) & 1.12 liter & 9.7 \\
\hline Pyraclostrobin (Cabrio EG) & $1.12 \mathrm{~kg}$ & 16.8 \\
\hline Trifloxystrobin (Flint) & $210 \mathrm{~g}$ & 20.0 \\
\hline Maneb (Maneb 75 DF) & $2.24 \mathrm{~kg}$ & 25.2 \\
\hline Dicloran (Botran 5F) & 7.0 liter & 27.0 \\
\hline Benzothiadiazole (Actigard $50 \mathrm{WG}$ ) & $93 \mathrm{~g}$ & 27.8 \\
\hline Untreated & $\ldots$ & 30.0 \\
\hline $\operatorname{LSD}(P=0.05)$ & & 7.68 \\
\hline \multicolumn{3}{|l|}{ Field trial 2003A } \\
\hline Pyraclostrobin + boscalid (Pristine) & $1.62 \mathrm{~kg}$ & 0.0 \\
\hline Boscalid (Endura) & $560 \mathrm{~g}$ & 0.0 \\
\hline Boscalid (Endura) & $399 \mathrm{~g}$ & 0.8 \\
\hline Cyprodinil + fludioxonil (Switch 62.5 WG) & $980 \mathrm{~g}$ & 1.3 \\
\hline Azoxystrobin (Quadris Flowable) & 1.12 liter & 7.1 \\
\hline Dicloran (Botran 5F) & 7.0 liter & 7.5 \\
\hline Azoxystrobin (Quadris Flowable) & 0.93 liter & 7.5 \\
\hline Trifloxystrobin (Flint) & $210 \mathrm{~g}$ & 9.2 \\
\hline Pyraclostrobin (Cabrio EG) & $1.12 \mathrm{~kg}$ & 10.8 \\
\hline Iprodione (Rovral 4F) & 2.34 liter & 10.9 \\
\hline Maneb (Maneb 75 DF) & $2.24 \mathrm{~kg}$ & 17.5 \\
\hline Benzothiadiazole (Actigard $50 \mathrm{WG}$ ) & $93 \mathrm{~g}$ & 26.7 \\
\hline Untreated & $\ldots$ & 29.2 \\
\hline $\operatorname{LSD}(P=0.05)$ & & 2.55 \\
\hline
\end{tabular}

${ }^{\mathrm{y}}$ Three applications of each treatment were applied beginning at lettuce thinning and continuing at $1-$ week intervals.

${ }^{\mathrm{z}}$ Mean percent evaluated plants that showed crown symptoms of Phoma basal rot. 
etiological evidence for a fungal agent. We focused on two products in particular. Azoxystrobin (Quadris Flowable) was already registered for use on lettuce in California and is most useful for controlling anthracnose caused by Microdochium panattonianum. Boscalid (Endura) was not registered for lettuce at the time of our field studies, although our data assisted in subsequent registration of this product for use on California lettuce and for control of Phoma basal rot. Endura is also used to manage lettuce drop caused by $S$. minor. In spring 2005, extensive acres of romaine in coastal California were treated with Endura, and Phoma basal rot incidence was significantly lower than in previous seasons.

While we report here a lettuce disease new to California and the United States, this problem has been observed in Europe previously. In the United Kingdom, a Phoma species was first associated with lettuce in 1965 when it was isolated from rotting stems of young field-grown plants in Gloucestershire (3). The species was not identified and pathogenicity tests were not undertaken. In 1990, a number of butterhead lettuce plants (cv. Ricardo) in a greenhouse in Essex were stunted and developed a wilt and collapse 3 weeks before harvest. Affected plants had a dry, mealy, red-brown stem rot at soil level; the heads snapped off easily when touched. In addition, dark gray to black leaf spots measuring 2 to $3 \mathrm{~cm}$ in diameter occasionally occurred on leaves in contact with or close to the soil (Fig. 4). The centers of spots sometimes fell out, leaving ragged margins. Pycnidia of a Phoma species were observed at the edges of the leaf spots and, less frequently, in rotting stem tissue. The leaf spot symptom and cavity pycnidia have not been observed on lettuce in California. However, environmental conditions for California romaine are quite different because the crop is grown in the field and not in greenhouses.

The fungus isolated in 1990 was identified as P. exigua var. exigua (C.A.B. International Mycological Institute isolate IMI 337207), and pathogenicity of the fungus to butterhead lettuce was proven. More recently (in 2003), we examined another $P$. exigua isolate from lettuce in the UK using the criteria in this study; this isolate (CC 543) was similar in morphology and $100 \%$ homologous in ITS sequence to the California isolates.

Presently in the UK, Phoma basal rot continues to affect greenhouse lettuce and is most severe in the winter months (November through February) and where yearround production is practiced (16). Losses of over $50 \%$ have occurred in some crops. This disease has also been reported on protected butterhead lettuce in Northern Ireland (D. Stokes, personal communication) and The Netherlands (A. Coolbergen, personal communication). Although the production of romaine lettuce in the UK has increased significantly in recent years, Phoma basal rot has not been recorded on this crop.

Greenhouse growers in the UK manage Phoma basal rot by avoiding prolonged periods of leaf wetness in the greenhouse, improving soil drainage, and applying sprays of prochloraz (Scotts Octave), pyraclostrobin + boscalid (Signum), or azoxystrobin (Amistar) (15). After a severe outbreak, growers might treat the soil with steam or dazomet (Basamid). Methyl bromide was also used for this purpose, although such use was curtailed as of December 2004 due to the Montreal Protocol on ozone-depleting substances.

Additional research on Phoma basal rot in California will focus on determining the source of initial inoculum, investigating

Table 6. Timing and rate studies for two fungicides for the control Phoma basal rot of romaine

\begin{tabular}{|c|c|c|}
\hline Treatment and rate/ha & Number of applications ${ }^{x}$ & Phoma basal rot $(\%)^{y}$ \\
\hline \multicolumn{3}{|l|}{ Field trial 2003B } \\
\hline Boscalid, $560 \mathrm{~g}$ & 2 & 0.0 \\
\hline Boscalid, $560 \mathrm{~g}$ & 1 & 0.3 \\
\hline Boscalid, $399 \mathrm{~g}$ & 2 & 0.3 \\
\hline Azoxystrobin, 1.12 liter & 2 & 0.3 \\
\hline Azoxystrobin, 0.93 liter & 2 & 0.9 \\
\hline Azoxystrobin, 1.12 liter & 1 & 3.4 \\
\hline Untreated & $\ldots$ & 12.5 \\
\hline $\operatorname{LSD}(P=0.05)$ & & 3.2 \\
\hline \multicolumn{3}{|l|}{ Field trial $2003 \mathrm{D}^{\mathrm{z}}$} \\
\hline Azoxystrobin, 1.12 liter & 1 & 10.3 \\
\hline Azoxystrobin, 1.12 liter & 2 & 10.3 \\
\hline Boscalid, $560 \mathrm{~g}$ & 1 & 10.6 \\
\hline Boscalid, $399 \mathrm{~g}$ & 2 & 14.1 \\
\hline Azoxystrobin, 0.93 liter & 2 & 16.6 \\
\hline Boscalid, $560 \mathrm{~g}$ & 2 & 19.1 \\
\hline Untreated & $\ldots$ & 21.9 \\
\hline $\operatorname{LSD}(P=0.05)$ & & 9.4 \\
\hline
\end{tabular}

the host range of lettuce isolates, and examining the possible epidemiological role of rotation crops such as strawberry (Fragaria $\times$ ananassa). Investigations of Phoma basal rot cases in the coastal region of California revealed that in a majority of situations a soil fumigant (methyl bromide + chloropicrin) application, followed by planting of strawberry transplants, preceded a spring planted romaine lettuce crop that developed severe Phoma basal rot (S. T. Koike, unpublished data). The possible association between the incidence of Phoma basal rot on lettuce following strawberry crops planted in fumigated soil is currently being investigated.

\section{ACKNOWLEDGMENTS}

The authors thank the following persons for assisting with this study: Mark Bolda, Rich Crandall, Steve Dobler, Hal Faulkner, Becky Grube, Patrick Headley, John Helm, Diana Henderson, Peter Iverson, Kat Kammeijer, Devin Kile, Ed Kurtz, Eric Lauritzen, Ken Lewis, Dan Marcum, Mark Mason, Phil Munger, Paul Reising, Ed Ryder, Bryan Shepherd, Tim Tidwell, Ben Valdez, and Edward Vega. We acknowledge Hal Faulkner, who first called our attention to this disease in California. This research was supported by the California Lettuce Research Board.

\section{LITERATURE CITED}

1. Abeln, E. C. A., Stax, A. M., de Gruyter, J., and van der Aa, H. A. 2002. Genetic differentiation of Phoma exigua varieties by means of AFLP fingerprints. Mycol. Res. 106:419-427.

2. Agricultural Commissioner's Office. 2005. Monterey County Crop Report 2004.

3. Baker, J. J. 1972. Report on diseases of cultivated plants in England and Wales for the years 1957 to 1968. Ministry of Agriculture, Fisheries and Food Technical Bulletin 25 . HMSO, London.

4. Boerema, G. H. 1969. The use of the term forma specialis for Phoma-like fungi. Trans. Br. Mycol. Soc. 52:509-513.

5. Boerema, G. H., de Gruyter, J., Noordeloos, M. E., and Hamers, M. E. C. 2004. Phoma identification manual. Differentiation of specific and infra-specific taxa in culture. CABI Publishing.

6. Boerema, G. H., and Howeler, L. H. 1967. Phoma exigua desm. and its varieties. Persoonia 5:15-28.

7. De Gruyter, J., Boerema, G. H., and van der Aa, H. A. 2002. Contributions towards a monograph of Phoma (Coelomycetes) VI-2. Section Phyllostictoides: Outline of its taxa. Persoonia 18:1-53.

8. de Hoog, G. S., and Gerrits van den Ende, A. H. G. 1998. Molecular diagnostics of clinical strains of filamentous basidiomycetes. Mycoses 41:183-189.

9. Erwin, D. C., and Ribeiro, O. K. 1996. Phytophthora Diseases Worldwide. American Phytopathological Society, St. Paul, MN.

10. Koike, S. T. 2001. Investigation of a new crown rot disease of lettuce. California Lettuce Research Board 2000-2001 Annual Report.

11. Koike, S. T., Subbarao, K. V., Verkley, G. J. M., O'Neill, T., and Fogle, D. 2003. Phoma basal rot of lettuce caused by $P$. exigua in California. (Abstr.) Phytopathology 93:S47.

12. Logan, C., and O'Neill, R. 1970. Production of an antibiotic by Phoma exigua. Trans. Br. Mycol. Soc. 55:67-75

13. Morgan-Jones, G., and Burch, K. B. 1988. Studies in the genus Phoma. XIII. Concerning Phoma exigua var. exigua, a cosmopolitan, ubiquitous fungus on diseased and dead plant 
material. Mycotaxon 32:477-490.

14. Obermeier, C., Sears, J. L., Liu, H. Y., Schlueter, K. O., Ryder, E. J., Duffus, J. E., Koike, S. T., and Wisler, G. C. 2001. Characterization of distinct Tombusviruses that cause diseases of lettuce and tomato in the Western United States. Phytopathology 91:797-806.

15. O`Neill, T. M., Bennison, J., and Gaze, R. H. 2000. Pests and diseases of protected vegetables and mushrooms. Pages 317-373 in: Pest and Disease Management Handbook. D. V. Alford, ed. Blackwell Science, Oxford.

16. O’Neill, T. M., and Stokes, D. 2001. Disease control in protected lettuce. HDC Factsheet 07/01. Horticultural Development Council, East Malling, Kent, England.

17. Rayner, R. W. 1970. A mycological colour chart. Commonwealth Mycological Institute.

18. Sutton, B. C. 1980. The Coelomycetes. Commonwealth Mycological Institute.

19. U.S. Dep. Agric. 2004. Vegetables-Annual Summary. USDA National Agricultural Statistics Service. Online publication.

20. van der Aa, H. A., Boerema, G. H., and de Gruyter, J. 2000. Contributions towards a monograph of Phoma (Coelomycetes) VI-1. Section Phyllostictoides: Characteristics and nomenclature of its type species Phoma exigua. Persoonia 17:435-456.

21. Vilgalys, R., and Hester, M. 1990. Rapid genetic identification and mapping of enzymatically amplified ribosomal DNA from sev eral Cryptococcus species. J. Bacteriol. 172:4238-4246.

22. White, T. J., Bruns, T., Lee, S., and Taylor, J. 1990. Amplification and direct sequencing of fungal ribosomal RNA genes for phylogenetics. Pages 315-322 in: PCR Protocols: A Guide to Methods and Applications. M. A. Innis, D. H. Gelfand, J. J. Sninsky, and T. J. White, eds. Academic Press, New York. 